(c) American Dairy Science Association, 2006.

\title{
Parturition and Hypocalcemia Blunts Calcium Signals in Immune Cells of Dairy Cattle ${ }^{1}$
}

\author{
K. Kimura, ${ }^{2}$ T. A. Reinhardt, and J. P. Goff \\ USDA, Agricultural Research Service, National Animal Disease Center, Periparturient Diseases of Cattle Research Unit, Ames, IA 50010-0070
}

\begin{abstract}
The stress of parturition in the dairy cow is associated with increased susceptibility to infectious disease. During the periparturient period the demands for calcium are increased; these increased demands for calcium can result in subclinical or clinical hypocalcemia. Periparturient cows also experience significant immune suppression. Because intracellular calcium signaling is a key early feature in immune cell activation, we have hypothesized that the increased demand for calcium in periparturient cows may adversely affect intracellular calcium stores of immune cells. This reduction in intracellular calcium stores in immune cells could blunt intracellular calcium release following an activating stimulus, contributing to the immune suppression seen in these animals. To test this hypothesis, peripheral mononuclear cells were obtained from 27 multiparous dairy cows spanning a period of $2 \mathrm{wk}$ before and $2 \mathrm{wk}$ after parturition. Following activation of these cells by anti-CD3 antibodies plus secondary antibodies, intracellular calcium release from intracellular stores was measured. The intracellular calcium released in response to the activation signal declined as calcium demand for lactation became more intense and recovered as plasma calcium normalized. Intracellular calcium stores in peripheral mononuclear cells, estimated by pretreating cells with pervanadate and ionomycin, significantly decreased at parturition and returned to normal levels as the cows' blood calcium returned to normal levels. Hypocalcemia, which is common in periparturient dairy cows, is associated with decreased intracellular calcium stores in peripheral mononuclear cells. Our data suggest that this is the cause of a blunted intracellular calcium release response to an immune cell activation signal. It is concluded that intracellular $\mathrm{Ca}$ stores decrease in peripheral blood mononuclear cells (PBMC)
\end{abstract}

\footnotetext{
Received December 2, 2005.

Accepted February 2, 2006.

${ }^{1}$ Names are necessary to report factually on available data; however, the USDA neither guarantees nor warrants the standard of the product, and the use of the name by USDA implies no approval of the product to the exclusion of others that may also be suitable.

${ }^{2}$ Corresponding author: kkimura@nadc.ars.usda.gov
}

before parturition and development of hypocalcemia. This suggests that systemic calcium stress precedes measurable hypocalcemia, particularly in cows that will develop milk fever. Therefore, PBMC intracellular Ca stores are a more sensitive measure of calcium stresses in transition cow. This decrease in PBMC intracellular $\mathrm{Ca}$ stores before parturition and the development of hypocalcemia contributes to periparturient immune suppression.

Key words: endoplasmic reticulum, flow cytometry, immunosuppression, signal transduction

\section{INTRODUCTION}

The stress of parturition and initiation of lactation in dairy cows is associated with increased susceptibility to diseases such as mastitis, Johne's disease (Chiodini et al., 1984), and Salmonellosis (Fossler et al., 2005) during the periparturient period. During the periparturient period, dairy cows suffer marked immune suppression as well as moderate to severe hypocalcemia (Reinhardt et al., 1988; Goff and Horst, 1997). The function of peripheral blood mononuclear cells (PBMC) and neutrophils declines as cows approach parturition and does not recover until 2 to $3 \mathrm{wk}$ after parturition (Kehrli et al., 1989a,b). The mechanism for this periparturient immunosuppression is unknown. However, we recently reported that periparturient cows that have had their mammary glands surgically removed do not develop hypocalcemia and do not suffer from the same degree of immune suppression as intact, milk-producing periparturient cows (Goff and Kimura, 2002; Nonnecke et al., 2003).

A key early feature in immune cell activation is an increase in intracellular ionized calcium concentration $\left(\left[\mathbf{C a}^{2+}\right]_{\mathbf{i}}\right)$, which acts as a second messenger of signal transduction (Grafton and Thwaite, 2001; Lewis, 2001). The degree of this initial rise in $\left[\mathrm{Ca}^{2+}\right]_{\mathrm{i}}$ following an activation signal is an indicator of immune cell responsiveness and function (Partiseti et al., 1994; Baus et al., 1996). Some studies have shown that hypocalcemia in the rat can reduce hepatocyte intracellular $\mathrm{Ca}^{2+}$ pools, which blunts release of intracellular $\mathrm{Ca}^{2+}$ in response to hormones such as phenylephrine (GasconBarre et al., 1994, 1997; Mailhot et al., 2000). In their 
model, which utilized vitamin D-deficient rats, they found that decreased $\mathrm{Ca}$ stores in endoplasmic reticulum (ER) were associated with decreased Ca-binding proteins within hepatocytes (Mailhot et al., 2000).

The high Ca demand for milk production is often associated with hypocalcemia in dairy cows. This may affect the amount of releasable $\mathrm{Ca}^{2+}$ stored inside the ER of immune cells, thus impairing $\left[\mathrm{Ca}^{2+}\right]_{\mathrm{i}}$ response to stimulation of bovine immune cells.

The data presented in this paper support the hypothesis that immune cells from cows with hypocalcemia have decreased intracellular $\mathrm{Ca}^{2+}$ storage, which is responsible for a blunted $\left[\mathrm{Ca}^{2+}\right]_{\mathrm{i}}$ response to activation.

\section{MATERIALS AND METHODS}

\section{Animals}

The Animal Care and Use Committee of the USDAARS-National Animal Disease Center approved all animal procedures. Multiparous periparturient cows ranging from 5 to $9 \mathrm{yr}$ of age (25 Jerseys and 2 Holsteins) were used in the periparturient studies. Jugular vein blood was collected 3 times a week (at $0700 \mathrm{~h}$ ) using acid citrate dextrose as anticoagulant for determination of PBMC $\left[\mathrm{Ca}^{2+}\right]_{\mathrm{i}}$ response to stimulation. Heparinized blood samples were collected every day (at $1300 \mathrm{~h}$ ) from about 2 wk before until 2 wk after parturition for plasma $\mathrm{Ca}$ analysis. In addition, 5 Jersey cows diagnosed with milk fever in the National Animal Disease Center dairy herd were used to assess the $\left[\mathrm{Ca}^{2+}\right]_{\mathrm{i}}$ response to activation before and several hours after treatment of milk fever.

\section{Measurement of Plasma Level of Ca}

Plasma was isolated from heparinized blood samples and stored at $-80^{\circ} \mathrm{C}$ until analysis. Plasma Ca concentration was determined by atomic absorption spectrophotometer (Perkin-Elmer, 1965).

\section{Reagents to Measure Intracellular Ca by Flow Cytometry}

The calcium-sensitive dyes, fluo-4-acetoxymethylester (AM) and Fura Red-AM, were obtained from Molecular Probes, Inc. (Eugene, OR). Fifty micrograms each of Fluo- 4 and Fura Red were dissolved in $5 \mu \mathrm{L}$ of anhydrous methyl sulfate (Aldrich Chemical Co., Inc., Milwaukee, WI), and kept in the dark at room temperature $\left(\sim 22^{\circ} \mathrm{C}\right)$. These stock solutions were used within $1 \mathrm{wk}$ after preparation. Stock solutions were diluted with PBS (8.5 g of sodium chloride, $1.1 \mathrm{~g}$ of sodium phosphate dibasic, and $0.32 \mathrm{~g}$ of sodium phosphate monobasic in $1 \mathrm{~L}$ of $\mathrm{H}_{2} \mathrm{O}, \mathrm{pH}=7.2 \pm 0.05$ ) before use. Antibovine-
CD3 mAb (mouse IgG ; $_{1}$ VMRD Inc., Pullman, WA) was diluted with PBS $(0.125 \mathrm{mg} / \mathrm{mL})$ and stored at $4^{\circ} \mathrm{C}$. Goat antiserum to mouse IgG (whole molecule, ICN, Aurora, $\mathrm{OH}$ ) was reconstituted with sterilized distilled water to $10 \mathrm{mg} / \mathrm{mL}$, and stored at $-20^{\circ} \mathrm{C}$ until use. Pluronic F127 (Molecular Probes, Inc.) was dissolved in anhydrous methyl sulfate (with heating) to make a $20 \%$ (wt/ vol) solution, and kept in the dark at room temperature. The working solution of Pluronic F127 was prepared by diluting stock solution 1/600 with PBS. Sodium orthovanadate (Sigma, St. Louis, MO) was dissolved in Krebs-Ringer bicarbonate/HEPES buffer (118.5 $\mathrm{mM}$ $\mathrm{NaCl}, 4.7 \mathrm{~m} M \mathrm{KCl}, 2.5 \mathrm{~m} M \mathrm{CaCl}_{2}, 1.2 \mathrm{~m} M \mathrm{KH}_{2} \mathrm{PO}_{4}$, $1.2 \mathrm{~m} M \mathrm{MgSO}_{4}, 24.9 \mathrm{~m} M \mathrm{NaHCO}_{3}, 30 \mathrm{~m} M$ HEPES, $\mathrm{pH}=6.8$ ) to produce a $5 \mathrm{mM}$ solution (Kadota et al., 1987). Pervanadate $(4.2 \mathrm{mM})$ was made by mixing 5 volumes of sodium orthovanadate $(5 \mathrm{mM})$ with 1 volume of $270 \mathrm{~m} M$ hydrogen peroxide. Pervanadate was added to cell preparations after $10 \mathrm{~min}$ of preparation and within $6 \mathrm{~h}$ to achieve a final concentration of $100 \mu M$. Ionomycin was obtained from Calbiochem-Novabiochem Corp. (San Diego, CA) and dissolved in anhydrous methyl sulfate to make $1 \mathrm{~m} M$ solution and stored at $-20^{\circ} \mathrm{C}$ until use. Ethylene glycol-bis (beta-aminoethylether)-N,N,N',N'-tetra acetate (EGTA) buffer was prepared by dissolving 3-(N-morpholino)-propane-sulfonic acid (MOPS, $20 \mathrm{mM}), \mathrm{KCl}(140 \mathrm{~m} M)$, NaCl $(20 \mathrm{mM})$, EGTA $(0.1 \mathrm{mM})$ in $\mathrm{H}_{2} \mathrm{O}, \mathrm{pH}=6.8$.

\section{Measurement of $\left[\mathrm{Ca}^{2+}\right]_{i}$ by Measuring Fluo-4 and Fura Red Emission from PBMC}

Fluo-4-acetoxymethylester emission increases with increasing cytosol-ionized calcium concentration, whereas Fura Red emission decreases with increasing cytosol-ionized calcium concentration. The $\left[\mathrm{Ca}^{2+}\right]_{\mathrm{i}}$ response can be measured using Fluo-4 emission analysis alone. However, simultaneously measuring both the increase in Fluo-4 emission and the reduction in Fura Red emission with increasing free or ionized calcium content of cells during baseline and stimulated periods allows calculation of the change in Fluo-4 emission/ change in Fura Red emission (Oishi et al., 2001). This calculation results in a determination of $\left[\mathrm{Ca}^{2+}\right]_{i}$ response with less variation than using Fluo-4 emission alone. We determined this previously by using PBMC from 5 nonparturient cows obtained over 5 consecutive days with assays performed in triplicate (data not shown). The intraassay coefficients of variation for the $\left[\mathrm{Ca}^{2+}\right]_{\mathrm{i}}$ response to anti-CD3 mAb plus secondary antibodies $(\mathrm{Ab})$ were determined. The Fluo-4 and Fluo-4/ Fura Red ratios were $7.1 \pm 1.0$ and $5.7 \pm 1.2 \%$, respectively. Interassay variations were $13.3 \pm 1.6$ and $10.7 \pm$ $2.1 \%$ for Fluo-4 and Fluo-4/Fura Red ratio, respectively. 
Therefore, all data on $\left[\mathrm{Ca}^{2+}\right]_{\mathrm{i}}$ response to stimulation are expressed on the basis of the Fluo-4/Fura Red ratio.

\section{Loading Dyes into Cells for $\left[\mathrm{Ca}^{2+}\right]_{i}$ Measurement}

Within $1 \mathrm{~h}$ after collecting a blood sample in acid citrate dextrose, $200-\mu \mathrm{L}$ aliquots of whole blood were dispensed into a microtiter plate (U-shaped bottom, 96well). The plate was centrifuged at $500 \times g$ for $2 \mathrm{~min}$ and supernatant plasma was discarded. Red blood cells were lysed by adding $200 \mu \mathrm{L}$ of hypotonic lysing solution for $15 \mathrm{~s}$. Isotonicity was restored by adding $100 \mu \mathrm{L}$ of restoring solution (Burton and Kehrli, 1995). After centrifugation at $500 \times g$ for $2 \mathrm{~min}$, the supernatant was discarded, and the lysing process repeated. The remaining leukocytes were washed once with $200 \mu \mathrm{L}$ of PBS. Fluo-4-acetoxymethylester (final concentration of $2.8 \mu M$ ) and Fura Red-AM (final concentration of 5.7 $\mu M$ ) were added to cells together with Pluronic F127 (final concentration of $0.06 \%$ ). Pluronic F127 helps the calcium-detecting dyes to enter the leukocytes. Upon entry into cells, the AM group is cleaved from the Fluo4-AM and Fura Red-AM by various esterases and the deesterified Fluo-4 and Fura Red are trapped inside the cell, and can bind $\mathrm{Ca}^{2+}$ in the cytosol (Tsien, 1981). The cells were incubated for $30 \mathrm{~min}$ at $39^{\circ} \mathrm{C}$ in a humidified $\mathrm{CO}_{2}(5 \%)$ chamber. After loading the dyes, $100 \mu \mathrm{L}$ of PBS was added, the plate was centrifuged at $500 \times$ $\mathrm{g}$ for $2 \mathrm{~min}$, and the supernatant was discarded to remove dye that had not entered the cells. Cells were washed once more with $200 \mu \mathrm{L}$ of Hanks' balanced salt solution (HBSS) with $1.2 \mathrm{mM} \mathrm{CaCl} 2$ and resuspended in $200 \mu \mathrm{L}$ of the wash solution. When estimating ER Ca storage following pervanadate and ionomycin stimulation the EGTA buffer, which was free of calcium, was used in place of $\mathrm{HBSS}$ with $\mathrm{CaCl}_{2}$ to eliminate the possibility of extracellular $\mathrm{Ca}^{2+}$ entering the cells and contributing to changes in $\left[\mathrm{Ca}^{2+}\right]_{\mathrm{i}}$.

\section{Activation of PBMC to Measure $\left[\mathrm{Ca}^{2+}\right]_{i}$ Response Capability}

The cell suspension in each well was transferred into a tube, which contained $300 \mu \mathrm{L}$ of HBSS with $1.2 \mathrm{mM}$ $\mathrm{CaCl}_{2}$ to simulate normal blood ionized calcium content. For activation of the cells by the CD3 stimulation pathway, anti-CD3 $\mathrm{mAb}$ (final concentration of $1 \mu \mathrm{g} / \mathrm{mL}$ ) was added at this stage (before activation). All tubes were maintained at $39^{\circ} \mathrm{C}$ using a block heater for 5 to $6 \mathrm{~min}$ before acquisition of data. Measurements of fluorescence were performed with a flow cytometer (FACScan, Becton Dickinson, San Jose, CA) using an argon-ion laser for excitation. Peripheral blood mononuclear cells were gated from debris and neutrophils based on forward vs. side scatter of light (Kimura et al., 1999). The Fluo- 4 and Fura Red dyes were excited at $488 \mathrm{~nm}$; Fluo- 4 emission was detected at 515 to 535 $\mathrm{nm}$ and Fura Red emission was detected at 665 to $685 \mathrm{~nm}$.

Peripheral blood mononuclear cells were analyzed at $39^{\circ} \mathrm{C}$ at a flow rate of 400 cells/s. Baseline, unstimulated measurements of Fluo-4/Fura Red ratio were made for $20 \mathrm{~s}$. Then, intracellular $\mathrm{Ca}^{2+}$ release was measured in response to addition of goat antimouse IgG. The binding of the goat antimouse antibody to the anti-CD3 mAb completes initiation of PBMC activation (Vassilopoulos et al., 1997). Measurement of Fluo-4 and Fura Red emission was continued for an additional $90 \mathrm{~s}$. The fold change in Fluo-4/Fura Red ratio between baseline and stimulated PBMC was calculated for each well.

\section{Estimation of $\mathrm{ER} \mathrm{Ca}^{2+}$ Stores}

To estimate ER Ca stores, pervanadate was added to cells after the baseline measurements instead of antiCD3 mAb-secondary Ab complex. The cells were also maintained in the calcium-free EGTA buffer, and $\left[\mathrm{Ca}^{2+}\right]_{\mathrm{i}}$ was measured for the next $150 \mathrm{~s}$. The pervanadate solution contained hydrogen peroxide, which activates PBMC by stimulating tyrosine kinases (Schieven and Ledbetter, 1994). Pervanadate interferes with calcium-ATPases of cell plasma membrane and ER membrane (Fantus et al., 1989), preventing calcium released to the cytosol from ER (or entering the cell from the extracellular fluids) from being returned to the ER or pumped to the extracellular fluids. Consequently, $\mathrm{Ca}^{2+}$ builds up within the cytosol of the cell until the ER is exhausted of its releasable $\mathrm{Ca}^{2+}$ stores. This was followed by ionomycin treatment $(1 \mu M)$ of the same cells for the next $150 \mathrm{~s}$ during which time $\left[\mathrm{Ca}^{2+}\right]_{\mathrm{i}}$ was measured. Ionomycin, a Ca ionophore, opens calcium channels in membranes including the cell membrane and the ER membrane and represents a second means of ensuring total releasable $\mathrm{Ca}$ stored within organelles has been released to the cytosol. Because this assay was performed in Ca-free medium, there is no contribution of extracellular $\mathrm{Ca}^{2+}$ to any increase in $\left[\mathrm{Ca}^{2+}\right]_{\mathrm{i}}$ measured by this method (Telford and Miller, 1996; Salvador and Mata, 1998). The change in Fluo-4/Fura Red ratio between baseline and pervanadate/ionomycinstimulated periods was calculated for each well (Roderick et al., 1998).

\section{Analysis of Flow Cytometry Data}

The data were stored in a "list mode" format and then Fluo-4 or Fura Red vs. time was analyzed using Cell Quest (Becton Dickinson) and saved as flow cytometry 
standard mode. Kinetic analysis of Fluo-4 or Fluo-4/ Fura Red ratio vs. time as mean value of individual cells was done using Flow Jo software (Tree Star, Inc., San Carlos, CA) to determine peak response in $\left[\mathrm{Ca}^{2+}\right]_{\mathrm{i}}$ flux when anti-CD3 mAb-secondary Ab complex was the stimulant, and area under the curve of Fluo-4/Fura Red ratio over time to determine Fluo-4/Fura Red ratio when pervanadate/ionomycin were used to estimate releasable ER $\mathrm{Ca}^{2+}$ stores.

\section{Statistical Analysis}

Data were analyzed by repeated measures using the PROC MIXED of SAS (version 9.1, SAS Inst., Inc., Cary, NC). The model included the fixed effects of disease status (milk fever vs. nonmilk fever), day (time around parturition), and disease status $\times$ day interaction, the random effect of cows nested within disease status, and the residual error. For each variable analyzed, cow nested within treatment was subjected to 3 covariance structures: compound symmetry, autoregressive order 1 , and unstructured covariance. The covariance that resulted in the Akaike's information criterion closest to zero was used. In all cases, it was the autoregressive order 1 covariance structure. Means and SEM are reported for all data. When significant effects $(P<0.05)$ due to disease status, day, or disease status $\times$ day interactions were detected, means separation was conducted by the Duncan-Hsu option in SAS. Correlation analysis was done using the CORR procedure of SAS using data from $d-11,0$, and 11 to see if significant correlations existed between $\left[\mathrm{Ca}^{2+}\right]_{i}$ response and the level of releasable ionized Ca stored in the ER. We also analyzed for correlations between plasma $\mathrm{Ca}$ and the $\left[\mathrm{Ca}^{2+}\right]_{\mathrm{i}}$ response or the level of releasable ionized $\mathrm{Ca}$ stored in the ER. The mean lymphocyte $\left[\mathrm{Ca}^{2+}\right]_{\mathrm{i}}$ responses to stimulation before and after intravenous calcium infusion into milk fever cows were compared by Student's 2tailed $t$-test.

\section{RESULTS}

\section{General Observations}

Eight cows developed clinical signs (recumbency and low body temperature) of hypocalcemia [milk fever $(\mathbf{M F})]$ on the day of calving or the next day. Blood samples were taken from these cows before intravenous treatment with calcium. Another 19 cows did not develop milk fever although they were hypocalcemic. These cows were referred to as the nonmilk fever (NMF) cows.

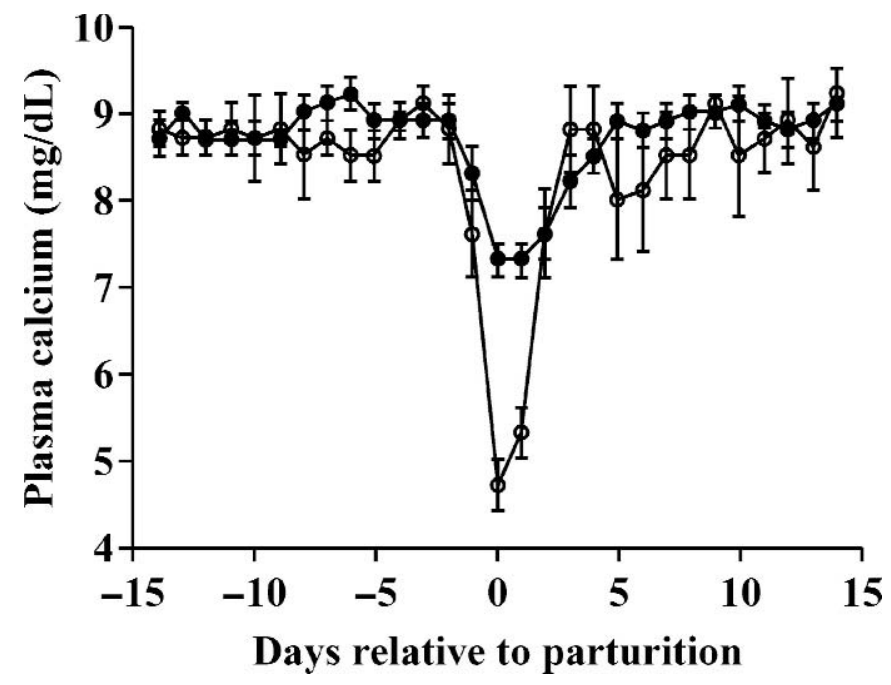

Figure 1. Plasma calcium concentrations (mean \pm SEM) around the time of parturition in milk fever $(\mathrm{O} ; \mathrm{n}=8)$ and nonmilk fever ( $\mathrm{n}=19)$ cows; d $0=$ day of parturition.

\section{Plasma Ca Concentration}

Plasma Ca concentrations of MF and NMF cows during the periparturient period are shown in Figure 1. The Ca concentration was maintained within normal limits $(8.5$ to $9.5 \mathrm{mg} / \mathrm{dL})$ until around the time of calving, when it dropped dramatically with the nadir the day of calving or the day after (NMF: $7.3 \pm 0.2 \mathrm{mg} /$ $\mathrm{dL}, \mathrm{MF}: 4.7 \pm 0.3 \mathrm{mg} / \mathrm{dL}$ ). Plasma Ca concentrations returned to nearly normal levels by $\mathrm{d} 4$. Repeated measures ANOVA found significant time $(P<0.0001)$, milk fever $(P=0.003)$, and time $\times$ milk fever interaction effects $(P<0.0001)$.

\section{Changes in $\left[\mathrm{Ca}^{2+}\right]_{i}$ Response in Periparturient Dairy Cows}

The changes in PBMC $\left[\mathrm{Ca}^{2+}\right]_{\mathrm{i}}$ in response to stimulation by anti-CD3 mAb-secondary Ab complex from $\mathrm{d}$ -11 to 11 around parturition are shown in Figure 2. The PBMC intracellular $\mathrm{Ca}^{2+}$ response showed a decline $(P=0.005)$ from $\mathrm{d}-11(2.25 \pm 0.05$ for NMF, $1.93 \pm 0.07$ for MF) to the day of calving (2.06 \pm 0.06 for NMF, 1.67 \pm 0.04 for $\mathrm{MF})$ and an increase $(P=0.03)$ after calving (d $11 ; 2.41 \pm 0.05$ for NMF, $1.86 \pm 0.12$ for MF). Repeated measures analysis showed significant time $(P=0.023)$ and milk fever $(P<0.0001)$ effects but no time $\times$ milk fever interaction. It is of interest that PBMC from cows that would develop milk fever showed significantly decreased $\left[\mathrm{Ca}^{2+}\right]_{\mathrm{i}}$ responses before the development of hypocalcemia associated with the milk fever episode. 


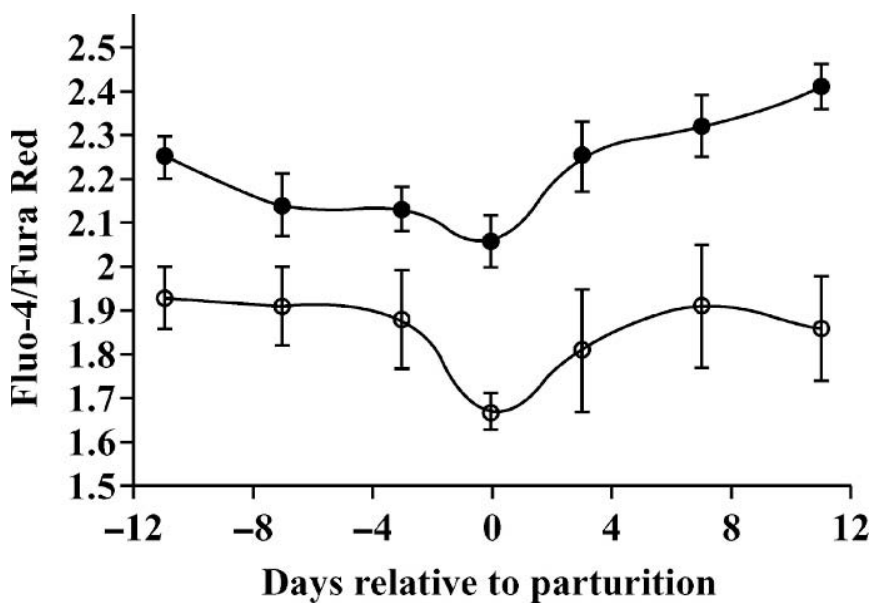

Figure 2. Flux of intracellular ionized calcium concentration $\left[\mathrm{Ca}^{2+}\right]_{\mathrm{i}}$ in peripheral blood mononuclear cells (mean \pm SEM.) in response to stimulation by anti-CD3 mAb-secondary antibody complex around the time of parturition in milk fever $(\bigcirc ; n=8)$ and nonmilk fever $(0 ; n=19)$ cows; $\left[\mathrm{Ca}^{2+}\right]_{\mathrm{i}}$ flux is reported as the ratio of fluo-4acetoxymethylester (Fluo-4)/Fura Red-acetoxymethylester (Fura Red) emission, and d $0=$ day of parturition.

\section{Effect of Intravenous Ca Infusion on $\left[\mathrm{Ca}^{2+}\right]_{i}$ Response in Clinically Hypocalcemic Cows}

Blood was obtained from 5 Jersey cows with clinical hypocalcemia and confirmed as having milk fever (recumbency, low body temperature, low blood calcium concentration) before and after they were treated with intravenous infusion of a $26 \% \mathrm{Ca}$ borogluconate solution $(500 \mathrm{~mL})$. Peripheral blood mononuclear cells were assessed in blood taken just before calcium infusion and from 5 to $30 \mathrm{~h}$ after calcium infusion. The PBMC $\left[\mathrm{Ca}^{2+}\right]_{\mathrm{i}}$ response was measured following stimulation with anti-CD3 mAb-secondary Ab complex. The $\left[\mathrm{Ca}^{2+}\right]_{\mathrm{i}}$ response in PBMC isolated from hypocalcemic cows increased from $1.83 \pm 0.14$ to $3.00 \pm 0.23(P<0.01$; Figure 3 ) following in vivo repletion of blood calcium with the calcium infusion.

\section{Estimation of Releasable $\mathrm{Ca}^{2+}$ Stored in ER and Correlation with $\left[\mathrm{Ca}^{2+}\right]_{i}$ Response and Plasma $\mathrm{Ca}$}

Total PBMC releasable $\mathrm{Ca}^{2+}$ stored inside the ER of periparturient cows' $\mathrm{PBMC}$ decreased before calving $(P=0.003)$ from the $\mathrm{d}-11$ value $(3.97 \pm 0.1$ for $\mathrm{NMF}$ and $3.53 \pm 0.25$ for $\mathrm{MF})$ to the $\mathrm{d} 0$ value $(3.54 \pm 0.13$ for NMF and $3.50 \pm 0.31$ for MF) and increased $(P=$ 0.0008 ) at $\mathrm{d} 11$ after calving ( $\mathrm{d} 11: 4.04 \pm 0.12$ for $\mathrm{NMF}$, $3.95 \pm 0.13$ for MF; Figure 4). The decrease in releasable $\mathrm{Ca}$ stores at calving was not significant in MF cows. It is interesting to note that releasable Ca stores in $\mathrm{MF}$ cows were much lower than in NMF cows at 7 and 11

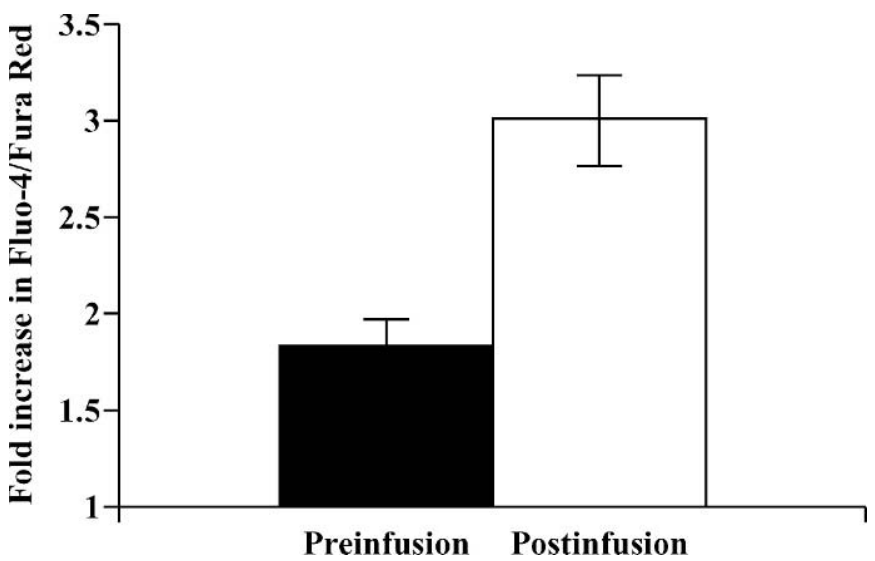

Figure 3. Mean \pm SEM $(n=5)$ effect of intravenous calcium infusion treatment on milk fever cows' $\mathrm{PBMC}\left[\mathrm{Ca}^{2+}\right]_{\mathrm{i}}$ flux in response to stimulation by antiCD3 $\mathrm{mAb}$-secondary antibody complex. $\left[\mathrm{Ca}^{2+}\right]_{\mathrm{i}}$ flux is reported as the ratio of Fluo-4/Fura Red emission.

$\mathrm{d}$ before calving. The statistical analysis established a significant time effect $(P=0.0016)$ but no milk fever or time by $\mathrm{MF}$ interaction effects. A correlation was observed between $\left[\mathrm{Ca}^{2+}\right]_{\mathrm{i}}$ response and releasable stores of ionized Ca from ER $(P=0.0355)$. Significant correlations between plasma $\mathrm{Ca}$ and $\left[\mathrm{Ca}^{2+}\right]_{\mathrm{i}}$ response $(P=$ 0.0013), and between releasable ionized Ca from ER and plasma $\mathrm{Ca}$ after calving $(P=0.0085)$ were also found. However, releasable stores of ionized $\mathrm{Ca}$ from

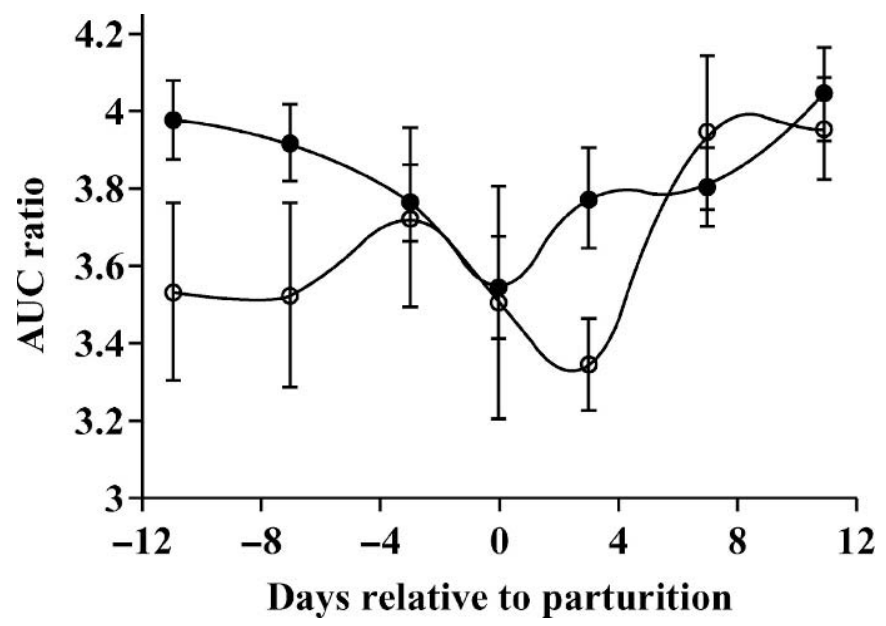

Figure 4. Endoplasmic reticulum (ER)-releasable calcium store size around the time of parturition in milk fever $(\bigcirc ; n=8)$ and nonmilk fever $(\mathbf{O}$; = 19) cows; ER Ca store size was estimated by determining intracellular ionized calcium concentration $\left[\mathrm{Ca}^{2+}\right]_{i}$ flux in peripheral blood mononuclear cells treated with pervanadate and ionomycin in Ca-free media. The ER Ca store size was expressed as the change in the area under the curve (AUC) of the ratio of fluo-4acetoxymethylester (Fluo-4)/Fura Red-acetoxymethylester (Fura Red) emission from baseline during pervanadate/ionomycin treatment period, and d $0=$ parturition. 
ER were not correlated to plasma Ca before calving $(P=$ 0.3898). This may be due to the observation that MF cows had a reduced $\left[\mathrm{Ca}^{2+}\right]_{\mathrm{i}}$ response to stimuli and reduced intracellular calcium stores before calving when compared with NMF cows.

\section{DISCUSSION}

Epidemiological evidence shows that cows with hypocalcemia are more susceptible to infectious disease (Curtis et al., 1983), and have a shorter herd life than cows without hypocalcemia (Duffield et al., 2005). A direct link between extracellular hypocalcemia in the periparturient dairy cow and immune cell function in periparturient dairy cows has yet to be demonstrated (Kehrli and Goff, 1989; Telford and Miller, 1996). However, recent work by Mailhot et al. (2000) has shown in vivo that extracellular fluid calcium status is a primary determinant of intracellular calcium status. They further demonstrated that depletion of intracellular $\mathrm{Ca}^{2+}$ blunted the increase in $\left[\mathrm{Ca}^{2+}\right]_{\mathrm{i}}$ response to hormones acting on hepatocytes. Because intracellular calcium signaling is a key early feature in immune cell activation, we have hypothesized that both the increased demand for calcium and hypocalcemia in the periparturient cow may adversely affect intracellular calcium stores of immune cells (Partiseti et al., 1994; Allen et al., 1995; Carruthers et al., 1996, 2000).

Stimulation of PBMC by anti-CD3 mAb-secondary Ab complex starts an activation cascade, which involves activation of tyrosine kinases that then phosphorylate phospholipase C- $\gamma$. Phosphorylated phospholipase C- $\gamma$ hydrolyzes inositol phospholipids in cell membranes, resulting in release of inositol 1,4,5-trisphosphate generation. Inositol 1,4,5-trisphosphate binds to receptors on the ER stimulating release of $\mathrm{Ca}^{2+}$ stored within the $\mathrm{ER}$ to the cytosol. This release of $\mathrm{Ca}^{2+}$ stored inside the ER can then stimulate an influx of extracellular $\mathrm{Ca}^{2+}$ into the cytosol via $\mathrm{Ca}^{2+}$ release-activated $\mathrm{Ca}^{2+}$ channels (Kurosaki, 1999; Lewis, 2001). The reduced $\left[\mathrm{Ca}^{2+}\right]_{\mathrm{i}}$ response to anti-CD3 mAb-secondary Ab complex stimulation observed in PBMC from periparturient cows (Figure 2) occurs at the same time as a reduction in other PBMC functions in periparturient cows (Kehrli et al., 1989a; Nonnecke et al., 2003). These data suggest that the decrease in PBMC functions seen as parturition approaches and their recovery after parturition may be the result of reduced PBMC $\left[\mathrm{Ca}^{2+}\right]_{\mathrm{i}}$ responsiveness.

Intracellular calcium signaling is a critical element for immune cell activation and functions. It regulates cell proliferation, cytokine production, and cytokine receptor expression as well as other cell functions (Partiseti et al., 1994; Allen et al., 1995; Carruthers et al., 1996, 2000). Individuals with conditions such as rheu- matoid arthritis of inflammatory bowel disease often have lymphocytes with depressed IL-2 production and IFN- $\gamma$ secretion. These lymphocytes also exhibit a depressed rise in $\left[\mathrm{Ca}^{2+}\right]_{\mathrm{i}}$ in response to mitogen or antiCD3 stimulation. This blunted response was also directly correlated with diminished lymphocyte proliferation activity (Allen et al., 1995). Such individuals with rheumatoid arthritis of inflammatory bowel disease do not have hypocalcemia; however, their lymphocytes do seem to have problems with distribution of calcium in the ER and other organelles, which prevents adequate calcium release.

The question arises as to the cause of the reduced PBMC $\left[\mathrm{Ca}^{2+}\right]_{i}$ response to stimuli in periparturient cows. Shortly after MF cows were treated with an i.v. infusion of $\mathrm{Ca}$, there was a significant increase in PBMC $\left[\mathrm{Ca}^{2+}\right]_{\mathrm{i}}$ flux in response to stimulation by anti-CD3 mAbsecondary Ab complex (Figure 3). Because the initial rise in $\left[\mathrm{Ca}^{2+}\right]_{\mathrm{i}}$ is caused by efflux of stored calcium from the ER followed by influx of extracellular $\mathrm{Ca}^{2+}$ and because this flux of $\mathrm{Ca}^{2+}$ goes on to open the $\mathrm{Ca}^{2+}$ releaseactivated $\mathrm{Ca}^{2+}$ channels needed to bring in extracellular $\mathrm{Ca}^{2+}$, we hypothesized that the decreased PBMC $\left[\mathrm{Ca}^{2+}\right]_{\mathrm{i}}$ responsiveness may be due to a decrease in ER calcium storage in the PBMC of periparturient cows. Using PBMC treated with a combination of pervanadate and ionomycin, we were able to demonstrate that the amount of ER Ca available for release to the cytosol decreases around the time of calving, which corresponds to the time when hypocalcemia is most commonly observed in cows. There was a good correlation between $\left[\mathrm{Ca}^{2+}\right]_{\mathrm{i}}$ responsiveness and amount of releasable $\mathrm{Ca}^{2+}$ stored inside the ER. The decrease in releasable $\mathrm{Ca}^{2+}$ stored within the ER was not necessarily well correlated with hypocalcemia, especially during the 1 to 2 wk before calving. Endoplasmic reticulum $\mathrm{Ca}^{2+}$ stores were being depleted in MF cows many days before the development of hypocalcemia and milk fever. These data suggest that intracellular Ca stores were being utilized to help sustain extracellular $\mathrm{Ca}$ or that when the cow is struggling to maintain Ca homeostasis (as colostrum is being formed within the mammary gland), the ability to keep ER Ca stores fully stocked is compromised. This observation suggests that the decreased $\left[\mathrm{Ca}^{2+}\right]_{\mathrm{i}}$ response is because of a decrease in the amount of releasable $\mathrm{Ca}^{2+}$ stored inside the ER of PBMC as the cow approaches parturition.

Our data showed that extracellular calcium status affects PBMC cellular calcium stores and thus, cellular calcium flux in response to signaling activation. These findings are in agreement with the data of Mailhot et al. (2000), who showed that hepatocytes isolated from hypocalcemic rats exhibited decreased $\left[\mathrm{Ca}^{2+}\right]_{i}$ flux in response to hormone stimulation, even when cells were 
suspended in media with normal extracellular $\mathrm{Ca}^{2+}$ concentration in vitro during hormone stimulation. Our data further challenge the prevailing hypothesis that extracellular $\mathrm{Ca}^{2+}$ has no significant impact on cellular $\mathrm{Ca}^{2+}$ by demonstrating that, despite the large $\mathrm{Ca}^{2+}$ gradient between extra- and intracellular $\mathrm{Ca}^{2+}$ concentrations, calcium deficiency in vivo significantly alters the response of immune cells to an activation stimulus.

Our data suggest that increased demand for $\mathrm{Ca}$ at the end of gestation and the onset of lactation results in decreased releasable $\mathrm{Ca}^{2+}$ stored inside ER in spite of well-maintained plasma calcium concentration up to parturition. We speculate that the immense demand for calcium before calving contributes to decreased intracellular $\mathrm{Ca}^{2+}$ stores even before hypocalcemia develops. Hypocalcemia at parturition further exacerbates the decline in the PBMC releasable $\mathrm{Ca}^{2+}$ stores. Because MF cows suffered the greater degree of hypocalcemia, the amount of Ca stored in their PBMC ER was lower and the flux of $\mathrm{Ca}^{2+}$ out of the ER in response to PBMC activation was smaller than in NMF cows. Further studies are needed to determine the mechanism of intracellular $\mathrm{Ca}^{2+}$ storage depletion and whether it might be associated with decreased $\mathrm{Ca}$ binding proteins as reported in rat hepatocytes (Mailhot et al., 2000).

\section{CONCLUSIONS}

There is decreased $\left[\mathrm{Ca}^{2+}\right]_{\mathrm{i}}$ flux in PBMC response to activation in the periparturient cow, which is associated with reduced stores of intracellular $\mathrm{Ca}$ in those cells. All of these effects are exacerbated in the cow that develops the severe hypocalcemia of milk fever during the periparturient period. Depletion of intracellular Ca stores likely starts several days before calving in the milk fever cow. These data demonstrate that periparturient immunosuppression in dairy cows is due, in part, to the decreased ability of the PBMC to mount a strong $\left[\mathrm{Ca}^{2+}\right]_{\mathrm{i}}$ flux in response to a signal that would ordinarily fully activate these cells.

\section{ACKNOWLEDGMENTS}

We are thankful to Peter Rabinovitch, Darren Hickerson, and Ray Hicks for their technical advice for flow cytometric analysis. Our appreciation also goes to Arlen Anderson for help in collection of blood samples, and Norman Tjelmeland and Creig Caruth for diligent animal care.

\section{REFERENCES}

Allen, M. E., S. P. Young, R. H. Michell, and P. A. Bacon. 1995. Altered T lymphocyte signaling in rheumatoid arthritis. Eur. J. Immunol. 25:1547-1554.
Baus, E., F. Andris, P. M. Dubois, J. Urbain, and O. Leo. 1996. Dexamethasone inhibits the early steps of antigen receptor signaling in activated T lymphocytes. J. Immunol. 156:4555-4561.

Burton, J. L., and M. E. Kehrli, Jr. 1995. Regulation of neutrophil adhesion molecules and shedding of Staphylococcus aureus in milk of cortisol-and dexamethasone-treated cows. Am. J. Vet. Res. 56:997-1006.

Carruthers, D. M., H. P. Arrol, P. A. Bacon, and S. P. Young. 2000. Dysregulated intracellular $\mathrm{Ca}^{2+}$ stores and $\mathrm{Ca}^{2+}$ signaling in synovial fluid $\mathrm{T}$ lymphocytes from patients with chronic inflammatory arthritis. Arthritis Rheum. 43:1257-1265.

Carruthers, D. M., W. G. Naylor, M. E. Allen, G. D. Kitas, P. A. Bacon, and S. P. Young. 1996. Characterization of altered calcium signalling in T lymphocytes from patients with rheumatoid arthritis (RA). Clin. Exp. Immunol. 105:291-296.

Chiodini, R. J., H. J. Van Kruiningen, and R. S. Merkal. 1984. Ruminant paratuberculosis (Johne's disease): The current status and future prospects. Cornell Vet. 74:218-262.

Curtis, C. R., H. N. Erb, C. J. Sniffen, R. D. Smith, P. A. Powers, M. C. Smith, M. E. White, R. B. Hillman, and E. J. Pearson. 1983. Association of parturient hypocalcemia with eight periparturient disorders in Holstein cows. J. Am. Vet. Med. Assoc. 183:559-561.

Duffield, T., S. L. E. Blanc, and K. Leslie. 2005. Impact of subclinical metabolic disease on risk of early lactation culling. J. Dairy Sci. 88(Suppl. 1):199-200. (Abstr.)

Fantus, I. G., S. Kadota, G. Deragon, B. Foster, and B. I. Posner. 1989. Pervanadate [peroxide(s) of vanadate] mimics insulin action in rat adipocytes via activation of the insulin receptor tyrosine kinase. Biochemistry 28:8864-8871.

Fossler, C. P., S. J. Wells, J. B. Kaneene, P. L. Ruegg, L. D. Warnick, L. E. Eberly, S. M. Godden, L. W. Halbert, A. M. Campbell, C. A. Bolin, and A. M. Zwald. 2005. Cattle and environmental sample-level factors associated with the presence of Salmonella in a multi-state study of conventional and organic dairy farms. Prev. Vet. Med. 67:39-53.

Gascon-Barre, M., P. Haddad, S. J. Provencher, S. Bilodeau, F. Pecker, S. Lotersztajn, and S. Vallierses. 1994. Chronic hypocalcemia of vitamin d deficiency leads to lower intracellular calcium concentrations in rat hepatocytes. J. Clin. Invest. 93:2159-2167.

Gascon-Barre, M., J.-L. Petit, C. Ethier, and S. Bilodeau. 1997. Hypocalcemia modifies the intracellular calcium response to the $\beta 1$ adrenergic agent phenylephrine in rat hepatocytes. Cell Calcium $22: 343-356$

Goff, J. P., and R. L. Horst. 1997. Physiological changes at parturition and their relationship to metabolic disorders. J. Dairy Sci. 80:1260-1268.

Goff, J. P., and K. Kimura. 2002. Effect of mastectomy on milk fever, energy, and vitamins $\mathrm{A}, \mathrm{E}$, and $\beta$-carotene status at parturition. J. Dairy Sci. 85:1427-1436.

Grafton, G., and L. Thwaite. 2001. Calcium channels in lymphocytes. Immunology 104:119-126.

Kadota, S., I. G. Fantus, G. Deragon, H. J. Guyda, and B. I. Posner. 1987. Stimulation of insulin-like growth factor II receptor binding and insulin receptor kinase activity in rat adipocytes. J. Biol. Chem. 262:8252-8256.

Kehrli, M. E., Jr., and J. P. Goff. 1989. Periparturient hypocalcemia in cows: Effects on peripheral blood neutrophil and lymphocyte function. J. Dairy Sci. 72:1188-1196.

Kehrli, M. E., Jr., B. J. Nonnecke, and J. A. Roth. 1989a. Alterations in bovine lymphocyte function during the periparturient period. Am. J. Vet. Res. 50:215-220.

Kehrli, M. E., Jr., B. J. Nonnecke, and J. A. Roth. 1989b. Alterations in bovine neutrophil function during the periparturient period. Am. J. Vet. Res. 50:207-214

Kimura, K., J. P. Goff, M. E. Kehrli, Jr., and J. A. Harp. 1999. Phenotype analysis of peripheral blood mononuclear cells in periparturient dairy cows. J. Dairy Sci. 82:315-319.

Kurosaki, T. 1999. Genetic analysis of B cell antigen receptor signaling. Annu. Rev. Immunol. 17:555-592.

Lewis, R. S. 2001. Calcium signaling mechanisms in T lymphocytes. Annu. Rev. Immunol. 19:497-521. 
Mailhot, G., J.-L. Petit, C. Demers, and M. Gascon-Barre. 2000. Influence of the in vivo calcium status on cellular calcium homeostasis and the level of the calcium-binding protein calreticulin in rat hepatocytes. Endocrinology 141:891-900.

Nonnecke, B. J., K. Kimura, J. P. Goff, J. Marcus, and E. Kehrli. 2003. Effects of the mammary gland on functional capacities of blood mononuclear leukocyte populations from periparturient cows. J. Dairy Sci. 86:2359-2368.

Oishi, H., S. Budel, A. Shuster, N. Stergiopulos, J. J. Meister, and J. L. Beny. 2001. Cytosolic-free calcium in smooth-muscle and endothelial cells in an intact arterial wall from rat mesenteric artery in vitro. Cell Calcium 30:261-267.

Partiseti, M., F. L. Deist, C. Hivroz, A. Fisher, H. Korn, and D. Choquet. 1994. The calcium current activated by $\mathrm{T}$ cell receptor and store depletion in human lymphocytes is absent in a primary immunodeficiency. J. Biol. Chem. 269:32327-32335.

Perkin-Elmer. 1965. Analytical methods for atomic absorption spectrophotometry. Perkin-Elmer Corp., Norwalk, CT.

Reinhardt, T. A., R. L. Horst, and J. P. Goff. 1988. Calcium, phosphorus, and magnesium homeostasis in ruminants. Vet. Clin. North Am. Food Anim. Pract. 4:331-350.
Roderick, H. L., D. H. Llewellyn, A. K. Campbell, and J. M. Kendall. 1998. Role of calreticulin in regulating intracellular $\mathrm{Ca} 2+$ storage and capacitative $\mathrm{Ca} 2+$ entry in $\mathrm{HeLa}$ cells. Cell Calcium 24:253-262.

Salvador, J. M., and A. M. Mata. 1998. Characterization of the intracellular and the plasma membrane $\mathrm{Ca}^{2+}$-ATPases in fractionated pig brain membranes using calcium pump inhibitors. Arch. Biochem. Biophys. 351:272-278.

Schieven, G. L., and J. A. Ledbetter. 1994. Activation of tyrosine kinase signal pathways by radiation and oxidative stress. Trends Endocrinol. Metab. 5:383-388.

Telford, W. G., and R. A. Miller. 1996. Detection of plasma membrane $\mathrm{Ca} 2+-\mathrm{ATPase}$ activity in mouse T lymphocytes by flow cytometry using Fluo-3-loaded vesicles. Cytometry 24:243-250.

Tsien, R. Y. 1981. A non-disruptive technique for loading calcium buffers and indicators into cells. Nature 290:527-528.

Vassilopoulos, D., R. B. Zurier, R. G. Rossetti, and G. C. Tsokos. 1997. Gammalinolenic acid and dihomogammalinolenic acid suppress the CD3-mediated signal transduction pathway in human T cells. Clin. Immunol. Immunopathol. 83:237-244. 